\title{
POTENSI GO-FUN (GOLD AND FUCOIDAN (SARGASSUM SP.) NANOPARTICLE) DALAM DIAGNOSTIK DAN TERAPI RETINOBLASTOMA
}

\author{
Sri Rezki Wahdania $\mathbf{J}^{\mathbf{1}}$, Indrasari ${ }^{2}$ \\ Universitas Islam Negeri Makassar \\ e-mail : rezkiwj04@gmail.com
}

\begin{abstract}
Retinoblastoma is one of the malignant diseases of the eye originating from embryonal tissue. This disease most often occurs in children aged less than 5 years. The prevalence of retionoblastoma ranges from 2-4\% of all pediatric malignancies with an incidence of 1 from 15,000-20,000 birth rates. This disease can occur unilaterally or bilaterally. The most common initial symptom is leukoria. The diagnosis of retinoblastoma are biopsy, X photos, ultrasound, Ct-Scan and MRI. However, this detection methods has side effects in children, so a diagnostic method is needed that has minimal side effects. As for the treatment of retinoblastoma are chemotherapy, surgery, focal therapy (cryotherapy, laser thermotherapy), external radiation and enucleation. However, this methods of therapy has side effects in the form of orbital bone growth disorders and mortality due to secondary malignancy. The use of chemotherapy not only attacks cancer cells but also can attack healthy cells so that patients can experience disorders such as diarrhea, anemia, etc. So from tha, the right and effective method of detection and therapy is needed.
\end{abstract}

The writing of this review is to examine the most effective and efficient detection and therapy methods for treating retinoblastoma. In this review, there were Pubmed and Google Scholar-based data searches and no factor index restrictions using the keywords Gold Nanoparticle, fucoidan, nanoparticle, retinoblastoma and Surgassum sp. A review showed that Gold Nanoparticle (GNP) effectively used in the detection of retinoblastoma and Fucoidan nanoparticle is effective for the treatment of retinoblastoma. Gold Nanoparticle $(G N P)$ and Fucoidan nanoparticle are potentially diagnostic and therapy on retinoblastoma.

Keywords

: fucoidan, Gold Nanoparticle, nanoparticle, retinoblastoma, Surgassum sp.

\begin{abstract}
Abstrak
Retinoblastoma merupakan salah satu penyakit keganasan pada mata yang berasal dari jaringan embrional. Penyakit ini paling sering terjadi pada anak dengan usia kurang dari 5 tahun. Prevalensi retionoblastoma berkisar 2-4\% dari seluruh keganasan pediatri dengan insiden 1 dari 15.000-20.000 angka kelahiran. Penyakit ini dapat terjadi secara unilateral maupun bilateral. Gejala awal yang paling sering muncul adalah leukoria. Adapun penegakan diagnosis pada retinoblastoma adalah biopsi, $\mathrm{X}$ foto, USG, Ct-Scan dan MRI. Namun metode deteksi ini memiliki efek samping pada anak sehingga dibutuhkan metode diagnostik yang memiliki efek samping yang minimal. Adapun untuk terapi retinoblastoma adalah kemoterapi, pembedahan, terapi fokal (krioterapi, termoterapi laser), radiasi ekterna dan enukleasi. Namun, metode terapi ini memiliki efek samping berupa gangguan pertumbuhan tulang orbita dan mortalitas akibat keganasan sekunder.Penggunaan kemoterapi bukan hanya menyerang sel kanker saja namun juga dapat menyerang sel sehat sehingga pasien dapat mengalami gangguan seperti diare, anemia, dan lain sebagainya. Maka dari itu, diperlukan metode deteksi dan terapi yang tepat dan efektif.

Penulisan review ini adalah untuk mengkaji metode deteksi dan terapi yang paling efektif dan efisien untuk mengatasi retinoblastoma. Dalam review ini adalah penelusuran data berbasis Pubmed dan Google Scholar dan tanpa pembatasan index factor dengan menggunakan kata kunci Gold Nanoparticle, fucoidan, nanopartikel, retinoblastoma dan Surgassum sp. Review menunjukkan bahwa Gold Nanoparticle (GNP) efektif digunakan dalam deteksi retinoblastoma dan Fucoidan nanoparticle juga efektif dalam terapi retinoblastoma. Gold Nanoparticle (GNP) dan Fucoidan nanoparticle berpotensi dalam diagnostik dan terapi retinoblastoma.
\end{abstract}

Kata kunci : : fucoidan, Gold Nanoparticle, nanopartikel, retinoblastoma, Surgassum sp. 


\section{PENDAHULUAN}

Retinoblastoma merupakan penyakit keganasan pada intraokuler yang berasal dari jaringan embrional paling sering terjadi pada anak-anak kurang dari 5 tahun dan dapat terjadi secara unilateral maupun bilateral. Sekitar 2-4\% dari keseluruhan keganasan pediatri, dengan insidens 1 dari 15.000-20.000 kelahiran hidup. Terdapat $60-75 \%$ penyakit ini terjadi unilateral dan terdiagnosis pada usia 24-30 bulan dan terdapat sebanyak $25 \%-40 \%$ terjadi secara bilateral dan terdiagnosis lebih mudah dengan median usia 12 bulan. Pasien retinoblastoma bilateral dan unilateral dengan riwayat keluarga retinoblastoma (herediter) menempati 30-40\%. Pasien retinoblastoma unilateral tanpa riwayat keluarga (non-herediter) menempati 60$70 \%$ kasus. Sedangkan $6-10 \%$ kasus memiliki riwayat keluarga dengan retinoblastoma ${ }^{1,2,3}$.

Retinoblastoma adalah suatu neuroblastik tumor ganas yang tidak berdeferiasiasi yang muncul dari lapisan retina manapun, dan secara biologik mirip dengan neuoblastoma dan meduloblastoma. Studi imunohistokimia menunjukkan bahwa sel tumor terwarnai positif pada enolase neuron-spesifik, fotoreseptor segmen ros-outer-S antigen spesifik, dan rhodopsin. Sel tumor juga menyekresi substansi ektrasel seperti interfotoreseptor retinoid-binding protein (produk normal fotorsesptor). Adanya sebagian kecil jaringan glial dalam retinoblastoma menunjukkan bahwa sel tumor dapat mempengaruhi kemampuan berdiferensiasi menjadi astroglia atau sel glial residen berproliferasi sebagai respon sel neoplasma primer. Gejala awal yang sering muncul pada retinoblastoma adalah leukoria (50-62\%), strabismus (20\%), hifema spontan, dan amourotik cat eye.diagnosis ditegakkan berdasarkan pemeriksaan $\mathrm{X}$ foto, USG, CT Scanatau MRI, dan LDH. Konseling genetik juga diperlukan dalam pemeriksaan pasien retinoblastoma dan penegakan diagnosis dari retinoblastoma. ${ }^{4}$

Penegakan diagnosis untun retinoblastoma secara umum dapat diketahui dengan pemeriksaan mata secara lengkap. Pemeriksaan awal meliputi pemeriksaan fungsi penglihatan, slit lamp biomikroskop pada vitreus dan segmen anterior bila memugkinkan dan oftalmoskop indirect dengan depresi sklera. Secara umum, diagnosis pasti retinoblastoma yang dapat digunakan yaitu dengan pemeriksaan patologi anatomi. Sehingga terdapat beberapa pemeriksaan penunjang yang dapat dilakukan untuk menegakkan diagnosis retinoblastoma yaitu: pemeriksaan $\mathrm{X}$ foto: dengan pemeriksaan ini hampir 60\%-70\% terdeteksi adanya kalsifikasi di dalam tumor, bila tumor mengadakan infiltrasi ke saraf optik, foramen optikum akan tampak melebar. pemeriksaan USG atau CT scan atau MRI: untuk mengetahui adanya massa tumor intraokuler meskipun media keruh. Tetapi pemeriksaan dengan radiasi sinar- $\mathrm{X}$ atau CT Scan dan MRI memiliki efek samping pada anak-anak. ${ }^{5}$

Penelitian terbaru mengungkap dampak negatif radiasi sinar-X atau CT Scan pada anak-anak, yang mana paparan radiasi dari ketiga pemeriksaan tersebut alat-alat tersebut bisa meningkatkan resiko terserang penyakit leukimia karena menggunakan sinar $\mathrm{X}$ yang merupakan radiasi yang terionisasi, ${ }^{5}$ selain dari harganya yang mahal pada pemeriksaan MRI. Penggunaan USG juga dapat digunakan karena mengurangi paparan radiasi pada anak tetapi tidak sensitif. Adapun pemeriksaan lain yang dapat dilakukan yaitu biopsi, dimana diagnosis pasti pada retinoblastoma dengan menggunakan tes patologi anatomi. Namun, tes ini harus di lakukan secara hati-hati karena bisa menyebabkan kontrindikasi, dan memerlukan waktu yang cukup lama untuk menunggu hasil dari biopsinya. ${ }^{6,7}$ Selain diagnosis yang tepat, diperlukan juga metode terapi yang efektif dalam pengobatan retinoblastoma. 
Terapi retinoblastoma yang digunakan adalah kemoterapi, pembedahan, terapi fokal (krioterapi, termoterapi laser), radiasi ekterna dan enukleasi. Radiasi ekterna sempat menjadi terapi utama pada sebagian besar retinoblastoma, dengan tingkat preservasi bola mata yang baik. Namun efek samping radiasi berupa gangguan pertumbuhan tulang orbita dan mortalitas akibat keganasan sekunder menyebabkan penggunan radiasi eksterna sebagai modalitas tatalaksana retinoblastoma telah berkurang. Penggunaan kemoterapi memiliki kekurangan yaitu kerjanya tidak spesifik, dimana kemoterapi juga dapat mengenai sel yang sehat sehingga muncul beberapa gejala pada pasien seperti lemah, dan mengalami gangguan seperti diare, anemia, mual dan muntah-muntah, sering pingsan, kerontokan rambut, dan konstipasi. Enukleasi sendiri memiliki efek samping perforasi dari bola mata. Sedangkan terapi dengan menggunakan karioterapi dapat mengakibatkan nekrosis jaringan dengan kedalam 5-6 mm. ${ }^{8,9}$ Berdasarkan premis diatas, diperlukan sebuah metode diagnostik dan terapi yang efektif dan bekerja secara spesifik dalam diagnosis dan terapi retinoblastoma yaitu dengan menggunakan Gold Nanoparticle (GNP) dan Fucoidan Nanoparticle dalam deteksi dan terapi retinoblastoma.

\section{METODE}

Metode yang digunakan adalah metode studi pustaka dari berbagai sumber ilmiah bereputasi dengan kriteria rilis 10 tahun terakhir. Literatur yang dipilih adalah literatur dengan metode eksperimental, tinjauan pustaka, dan kajian sistematis. Literatur review ini dibuat dari hasil penelusuran data penelitian-penelitian yang berkaitan dengan Gold nanoparticle (GNP) dalam mendeteksi retinoblastoma dan fucoidan nanoparticle dalam terapi tumor dan kanker berbasis PubMed dan Google Scholar dengan menggunakan kata kunci Gold Nanoparticle, fucoidan, nanoparticle, retinoblastoma dan Surgassum sp. Referensi juga diperoleh dari tesis. Referensi yang digunakan adalah artikel dengan menggunakan bahasa Indonesia dan Bahasa Inggris. Jumlah literatur yang didapatkan sejumlah 23 referensi, dimana 22 diantaranya adalah artikel jurnal dan 1 diantaranya merupakan referensi tesis. Penelusuran referensi tanpa pembatasan index factor, dan semua referensi yang didapatkan adalah free journal.

\section{HASIL DAN PEMBAHASAN}

\section{Diagnostik Retinoblastoma dengan Gold Nanoparticle (GNP)}

Gold Nano Particle (GNP) atau nanopartikel emas merupakan nanopartikel berbasis logam emas yang berpotensi digunakan untuk meningkatkan kualitas diagnosa penyakit, meningkatkan spesifikasi obat pada jaringan tertentu, serta menghantarkan dan menerima gelombang elektromagntik. ${ }^{10-13}$ GNP memiliki karakteristik khusus sehingga lebih unggul daripada nanopartikel lainnya karena ukuran molekulnya yang lebih besar dibandingkan dengan nanopartikel yang digunakan saat ini, nanopartikel ini lebih mudah terakumulasi pada jaringan kanker. Hal ini terjadi karena peningkatan permabilitas pembuluh darah disekitar sel kanker. ${ }^{10}$ Selain itu, GNP juga dapat menjaga kadar substansi yang dibawanya karena tidak ada molekul pada tubuh yang dapat berikatan dengan emas sehingga nanopartikel tidak akan terdestruksi. ${ }^{7}$

Untuk dapat mendeteksi sel kanker, kebanyakan sel kanker memiliki protein yang dikenal sebagai Epidermal Growth Factor Receptor (EFGR) di setiap permukaan, sementara itu sel yang sehat/ normal tidak mengekspresikan protein tersebut. Melalui konjugasi atau pengikatan, GNP dalam antibodi untuk EFGR atau anti-EFGR. GNP dapat menarik dirinya sendiri pada sel kanker. Ketika GNP mengikat sel kanker akan 
tampak dalam mikroskop bahwa sel kanker tersebut akan bersinar. Sel sehat/sel normal tidak akan mengikat GNP, sehingga sel tersebut tidak akan terlihat. Sehingga apabila didapatkan sel yang bersinar saat diberikan GNP, dapat dipatikan bahwa sel tersebut merupakan sebuah tumor atau kanker.
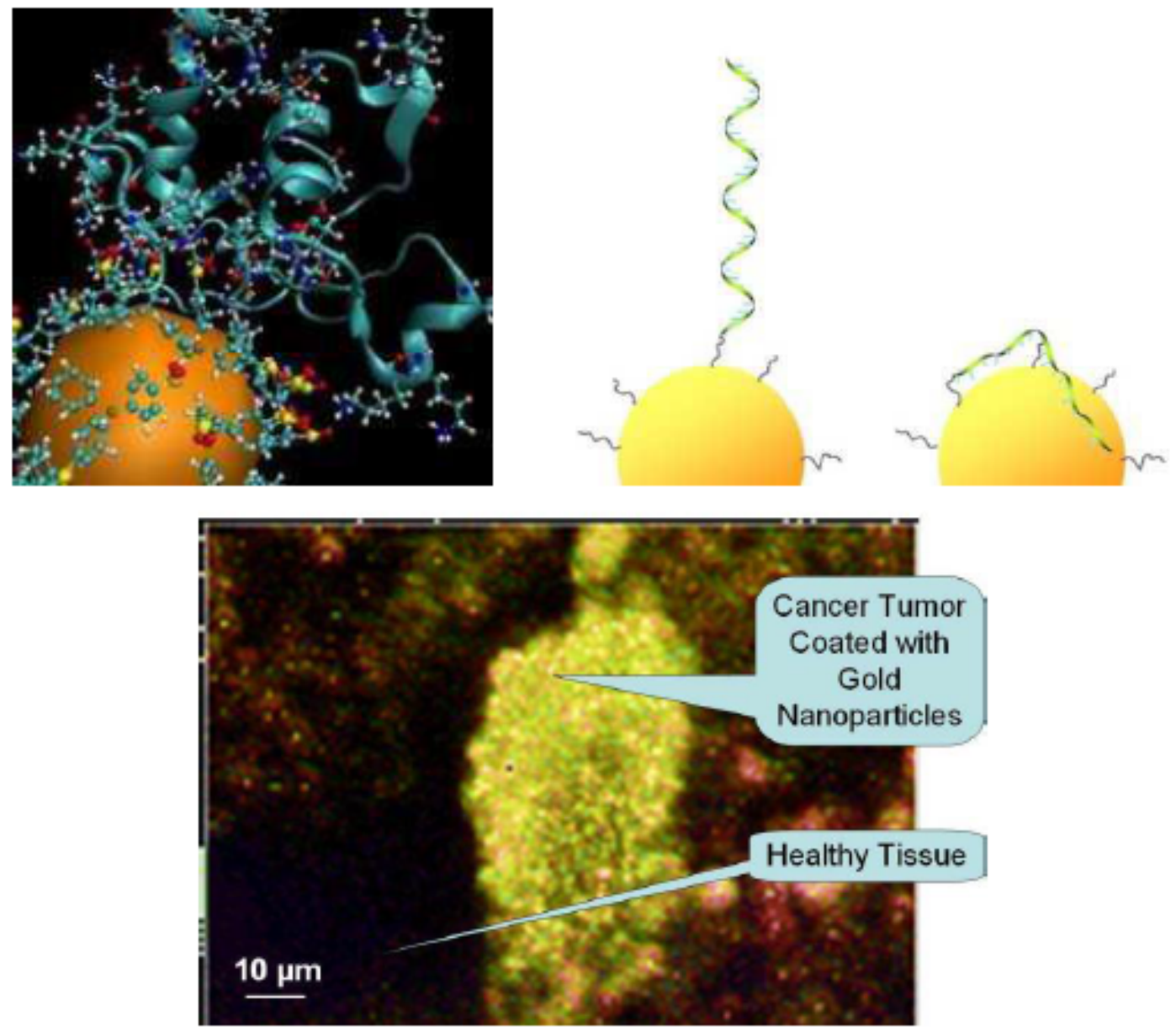

Gambar 1. Sel kanker dilapisi oleh Gold nanoparticle ${ }^{13}$

Afinitas GNP terhadap sel kanker $600 \%$ yang lebih besar dibandingkan afinitasnya terhadap sel bukan kanker, oleh karena itu teknologi GNP dapat digunakan untuk deteksi pada kanker mata ini (retinoblastoma). Selain penyerapan spektrum GNP yang dapat digunakan untuk membedakan sel kanker, kelebihan lain dari GNP adalah prosesnya cepat. Jika kita mengambil sel kanker dari sebuah jaringan kemudian menyemprotkannya dengan GNP kita akan dapat melihat hasilnya langsung. Selain itu teknik ini tidak berbahaya bagi sel tubuh. Teknologi GNP membuat pendeteksian kanker menjadi lebih mudah, cepat, dan tidak begitu mahal. Penggunaan GNP sebagai pendeteksi sel kanker diharapkan dapat membuat pengobatan kanker menjadi lebih efektif, karena pengobatan langsung tepat sasaran pada sel kankernya sehingga tidak merusak sel sehat yang lainnya.

\section{Terapi Retinoblastoma dengan Fucoidan Nanoparticle}

Fucoidan nanoparticle sangat berpotensi dalam terapi tumor dan kanker. Dimana fucoidan dalam nanopartikel ini memiliki kelebihan yaitu memiliki 
stabilitas yang tinggi dan biovailabilitas yang luar biasa. Sistem penghantaran obat berbasis nanoteknologi ini memiliki kemampuan untuk mengenkapsulasi berbagai obat, seperti molekul-molekul kecil (baik hidrofil maupun hidrofob), protein, peptida dan asam nukleat (DNA maupun RNA). ${ }^{14}$ Dengan mengenkapsulasi molekul-molekul tersebut dalam sistem nano karier, kelarutan dan stabilitas dapat diperbaiki serta memperbaiki profil farmakokinetik. Fucoidan nanopartikel dapat masuk ke dalam sitoplasma, dan langsung dihantarkan ke organ atau sel spesifik sehingga tidak memiliki dampak negatif terhadap sel yang lainnya. Berbeda dengan terapi retinoblastoma lainnya seperti radiasi yang dapat menimbulkan efek samping berupa gangguan pertumbuhan orbita. ${ }^{15}$ sehingga fuxoidan nanopartikel ini sangat memungkinkan digunakan dalam terapi retinoblastoma.

Fucoidan yang berasal dari rumput laut coklat (Sargassum sp.) merupakan sebuah tanaman yang telah terbukti dalam mengobati tumor maupun kanker. Tanaman ini berbentuk silindris atau gepeng yang memiliki banyak kandungan zat aktif seperti alkaloid, flavonoid, saponin, polifenol dan lain sebagainya yang berperan sebagai antiokasidan, antikanker, antiimflamasi, dan imunomodulator. Dimana kandungan dari zat aktif ini berperan dalam perubahan permeabilitas sel sehingga dapat menghambat pertumbuhan sel atau proses kematian sel. Fucoidan juga berperan dalam menghentikan metastase sel dengan menggunakan cell line $\mathrm{MCF}-7$ yang berkerja dengan mempengaruhi proses Bcl-2, Bcl-xL, Bcl-w, dan Bad sehingga menurunkan transformasi, imortilitas dan menurunkan timbulnya keganasan pada sel. Kematian dari sel kanker ini ditandai dengan terjadinya penyusutran sitoplasma dan kondensasi kromatin. Apoptosis terjadi melalui jalur ekstrinsik (sitoplasmik) di mana reseptor kematian sel memicu apoptosis atau jalur intrinsik (mitokondria) di mana perubahan dalam potensial membran mitokondria (MMP) menyebabkan pelepasan sitokrom $\mathrm{C}$ dan aktivasi sinyal kematian. Kedua jalur mengaktifkan caspase eksekutif yang memecah molekul pengatur dan struktural. Fucoidan memiliki kemampuan dalam menghancurkan sel kanker dengan cara menginduksi apatosis sel. Fuciodan dapat menurunkan proliferasi sel dengan cara mengurangi aktivitas ERK dan pembentukan koloni oleh sel-sel kanker secara in vitro. Hal tersebut dibuktikan dari penelitian Zhang dimana terjadi penurunan pertumbuhan sel kanker setelah pemberian fucoidan pada hewan coba yang bekerja menghambat proliferasi sel di cell line MDA-MB-231, MCF-7 dan 4T1.

Selain itu, fucoidan berperan sebegai agen antiangiogenik pada sel kanker sehingga secara tidak langsung dapat membunuh sel-sel kanker dengan mengurangi nutrisi melalui pembuluh darah baru (anti VEGF). Hal ini juga dibutikan pada penelitian Xue dkk (2012) bahwa fucoidan telah terbukti berperan sebagai anti VEGF (Vascular Endothelial Growth Factor). Penelitian Riu, dkk juga telah membuktikan bahwa efek antiangiogenesis fucoidan dan penurunan ekspresi STAT pathway. Fucoidan juga mengaktivasi caspase 8 dan 9 yang berperan dalam proses apatosis sel. Pada penelitian Coombee $\mathrm{dkk}$, fucoidan juga dapat menghambat metastasi dari sel tumor, dimana fucoidan menghambat invasi sel dengan pengikatan sel tumor dengan laminin pada membran basement. Fucoidan juga berikatan dengan fibronektin yang memiliki afinitas yang tinggi dan mencegah perlakatan dari sel tumor sehingga menghambat sel tumor untuk bermetastasis ke jaringan yang lain. Agen anti-proliferasi dari fucoidan juga menekan aktivitas MMP-2 serta menurunkan PI3K-Akt-mTOR pada jalur ERK1/2 dalam menghentikan metastasis kanker. Selain itu, fucoidan juga memiliki efek stimulasi kekebalan antikanker tubuh dengan mengaktivasi sel imun dan 
menstimulasi pembentukan sitokin antikanker. Fucoidan ini memicu THP-1 degan meningkatkan kadar IFN- $\gamma$, p53, Bax, TNFa, IL-12. Fucoidan juga menginduksi produksi dari interleukin-1 (IL-1) dan IFN- $\gamma$ secara in vitro, peningkatan fungsi dari Limfosit $\mathrm{T}$, sel $\mathrm{B}$, makrofag dan sel NK serta memberikan respon antibodi utama di Sheep Red Blood Cells (SRBC) secara in vivo sehingga efektif berperan dalam imunomodulasi dan imunosupresi tumor dan kanker. ${ }^{19,22}$

Pemberian fucoidan nanopartikel yang diberikan secara intravena akan masuk ke dalam pembuluh darah dan sirkulasi ke seluruh tubuh. Fucoidan nanopartikel ini akan menempel pada ligan reseptor makrofag kelas A menuju target tumor atau kanker baik melalui jalur intrinsik maupun ekstrinsik. Pada jalur ekstrinsik, fucoidan akan berdifusi ke reseptor sel kanker. Fucoidan yang berdifusi, menginduksi signal PI3K/Akt dan reseptor EGF-R yang spesifik terhadap sel kanker. Pada jalur instrinsik Fucoidan pada makrofag kelas A memroduksi IL-12 yang menginduksi pembentukan sel Natural Killer (NK) yang menuju ke mitokondria sel target.

Penelitian Satyarsan, 2019 menunjukkan bahwa fuciodan memiliki waktu paruh selama 48-72 jam dalam menghambat proliferasi dan apaptosis sel. Ekstrak fucoidan ini akan tetap menginduksi sinyal PI3K/AKT dalam sel kanker dan bertahan sampai mengalami apoptosis. Fucoidan ini juga tidak meninggalkan residu asing yang abnormal di dalam tubuh sehingga aman digunakan. Selain itu, fucoidan juga memiliki kelebihan lain yaitu dapat bekerja pada banyak sel target (multitarget) untuk mengindukasi apatosis melalui regulasi dari Bcl-2, Bad, Bax, kaspase 8-7-3, $\mathrm{pI} 3 \mathrm{k} / \mathrm{Akt} / \mathrm{mTOR}$, jalur MAPK, MMP-2, THP-1, JKN, ERK1/2 serta CDKs pada siklus sel kanker.

\section{KESIMPULAN DAN SARAN}

\section{Kesimpulan}

Gold nanoparticle (GNP) sangat berpotensi dalam deteksi retinoblastoma dan fucoidan nanoparticle efektif digunakan dalam terapi retinoblastoma. Dimana fucoidan menyerang langsung pada sel target dan mengapaptosis sel tumor maupun kanker.

\section{Saran}

Perlu dilakukan penelitian lebih lanjut tentang peranan GNP dan fucoidan nanoparticle dalam deteksi dan terapi tumor dan kanker khususnya pada retinoblastoma.

\section{DAFTAR PUSTAKA}

1. American Cancer Society. Cancer Facts And Figures. 2017. Genes Dev. 2017;21(20):2525-38.

2. Delhiwala Ks, Vadakkal Ip, Mulay K, Khetan V, Wick Mr. Retinoblastoma: An Update. Semin Diagn Pathol. 2016;33(3):133-40.

3. Ghassemi F, Khodabande A. Risk Definition And Man-Agement Strategies In Retinoblastoma: Current Perspec-Tives. Clin Ophthalmol. 2015;9:985-94.

4. Rares Laya. Retinoblastoma.Bagian Ilmu Kesehatan Mata Fakultas Kedokteran Universitas Sam Ratulangi Manado. Jurnal E-Clinic (Eci). 2016; 4 (2).

5. Orman A, Koru-Sengul T, Miao F, Markoe A, Panoff JE. The modern role of radiation therapy in treating advanced-stage retinoblastoma: Longterm outcomes and racial differences. Int $J$ Radiat Oncol Biol Phys. 2014;90(5):1037-43.

6. Fontanesi J, Taub J, Kirkpatrick Jp, Halperin Ec. Reti-Noblastoma. In: Halperin Ec, Constine Ls, Tarbell $\mathrm{Nj}$, Kun Le, Editors. Pediatric Radiation Oncology. 5th Ed. Philadelphia: Lippincot Williams \& Wilkins; 2011. P. 85-107. 
7. Prajapati Parimal M, Shah Yastri, And Sen D.J. (2010). Gold Nanoparticles: A New Approach For Cancer Detection. Http://Jocpr.Com/SecondIssue/J.\%20chem.\%20pharm.\%20res., 2010,\%202(1)\%2030-37.Pdf

8. Yanık O, Gunduz K, Yavuz K, Tacyildiz N, Unal E. Chemotherapy In Retinoblastoma: Current Approaches. Turk Oftalmoloiji Derg. 2015;45(6):259-67.

9. Kodrat H, Gondhowiardjo S.Radioterapi and Onkologi Indonesia. Journal of The Indonesian Radiation Oncology Society. 2013; 4 (1):17-23.

10. Dreaden Ec, Austin La, Mackey Ma, El-Sayed Ma. Size Matters: Gold Nanoparticles In Targeted Cancer Drug Delivery. Ther Deliv. 2012; 3(4):457-78.

11. Dreaden Ec, Mwakwari Sc, Sodji Qh, Oyelere Ak, El-Sayed Ma. Tamoxifen-Poly(Ethylene

Glycol)-Thiol Gold Nanoparticle Conjugates: Enhanced Potency And Selective Delivery For Breast Cancer Treatment. Bioconjug Chem. 2009;20(12):2247-53.

12. Von Maltzahn G, Centrone A, Park JH, Ramanathan R, Sailor Mj, Hatton Ta, Et Al. Sers-Coded Gold Nanorods As A Multifunctional Platform For Densely Multiplexed Near-Infrared Imaging And Photothermal Heating. Adv Mater. 2009;21(31):3175-80.

13. Rohadi Awaludin. (2009). Pembuatan Nanopartikel Emas Radioaktif dengan Aktivasi

Neutron.http://journal.ui.ac.id/technol ogy/article/view/495/491.

14. Chandra, Egy, Dkk. Studi Biodistribusi Dan Farmakokinetik Nanokarier Plga-Poloxamer Bertanda Radioisotop Iodium-131 Pada Mencit. 2014; 1(2): 39-47

15. Sinambela, Aurika, Dan H.M Djakaria. Radioterapi Dan Onkologi Indonesia. Journal of Indonesian
Radiation Oncology Society. 2017; 8 (2): 77-83.

16. Hervidea, Radella. 2017. Efek Ekstrak Metanol Makroalga Cokelat (Sargassum Sp.),Makroalga Merah (Gracillaria Sp.) Dan Taurin Terhadapgambaran Histopatologi Hepar Dan Ginjal Mencit Jantan (Mus Musculus) Yang Diinduksi Benzo(A)Piren (Tesis). Lampung: Universitas Lampung.

17. Sandapare, Martina, Dkk. 2015. Uji Aktivitas Antioksidan Dan Toksisitas Ekstrak Kasar Polisakarida Yang Diisolasi Dari Alga Coklat Sargassum Duplicatum. Makassar: Unhas.

18. Satyarsa, Agung B. Studi Pustaka: Potensi Fucoidan Dari Rumput Laut Coklat (Sargassum Sp.) Sebagai Inovasi Terapi Pada Kanker Payudara. Journal Of Medicine And Health. 2019; 2(3):909-919.

19. Aquib, Md, Dkk. A Review On The Chemotherapeutic Role Of Fucoidan In Cancer As Nanomedicine.Research Journal of Life Sciences, Bioinformatics, Pharmaceutical And Chemical Science. 2019; 5(1): 512537.

20. Zhang, Z.; Teruya, K.; Eto, H.; Shirahata, S. Fucoidan Extract Induces Apoptosis In Mcf-7 Cells Via A Mechanism Involving The RosDependent Jnk Activation And Mitochondria-Mediated Pathways. Plos One. 2011; 6(1).

21. Xue, M.; Ge, Y.; Zhang, J.; Wang, Q.; Hou, L.; Liu, Y.; Sun, L.; Li, Q. Anticancer Properties And Mechanisms Of Fucoidan On Mouse Breast Cancer In Vitro And In Vivo. Plos One .2012; 7 (4).

22. Coombe, D.R.; Parish, C.R.; Ramshaw, I.A.; Snowden, J.M. Analysis of The Inhibition Of Tumour Metastasis By Sulphated Polysaccharides. Int. J. Cancer 1987, $39,82-88$. 
AL-IQRA MEDICAL JOURNAL : JURNAL BERKALA ILMIAH KEDOKTERAN

e-ISSN : 2549-225X. Vol. 1 No. 2, Agustus 2018, Hal. 84-91

23. Senthilkumar K, Manivasagan $P$, Venkatesan J, Kim Sk. Brown Seaweed Fucoidan: Biological Activity And Apoptosis, Growth Signaling Mechanism In Cancer. International Journal of Biological Macromolecules. 2013;60:366-74. 